\title{
古代インド医学原典の寿命論
}

\section{吉 次 通 泰}

\section{1. 背景・目的・典拠}

寿命とは，個体の誕生から死に至るまでの期間（厳密には受精から死に至るまで の期間，個体の自己同一性の継続期間）である。最近，わが国では平均寿命が延び， 人間の最大寿命とされている 110 ～ 120 歳に近づきつつある長寿社会であるが， 必ずしも喜ばしいことばかりとは言えず,多くの社会的問題が持ち上がっている. 平均寿命が短かった古代インドでも長寿を願う呪文は多く，100 歳が理想であっ た（『リグ・ヴェーダ』7.66.16；10.18.4；『アタルヴァ・ヴェーダ」3.11.2-4, 7.53.2). 古代インド医学書でも，長寿を求める章から始まり，医学の目的は長寿を達成す ることであったと考えられる。本研究の目的は，代表的な古代インド医学原典で ある『チャラカ・サンヒター $(C S) 』(4 \mathrm{C} . \mathrm{AD})$ ，『スシュルタ・サンヒター $(S S)\rfloor(2-5 \mathrm{C}$.

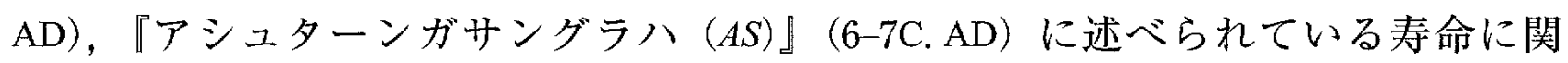
する記述を検討し，古代インドにおける寿命に対する見解を明らかにすることで ある。

\section{2 . 結果}

\section{年齿命:}

CS 3.8.12 は，「年歯令ある特定の時間の量（長さ）に依存する身体の状態」と 定義し, 大きく3つの時期一小监期 ( 16 歳), 中年期 ( 60 歳), 老年期 ( 100 歳）一に分類し，各時期の特性を述べている。このカリ時期では，寿命の限 度は 100 歳であるが, 100 歳より長く, あるいは短く生きる人がある, と追記し

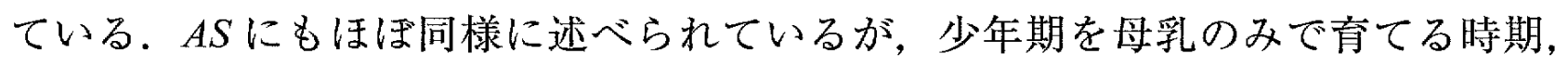
母乳と固形食の両者で育てる時期, 固形食のみで育てる時期の3つの時期に分け, 中年期もまた青年期 ( 30 歳), 完成期 ( 45 歳), 維持期 ( 60 歳) の3 種類に 分類している.「小児期, 身体の成長, 肌の輝き, 知能, 皮膚, 精子, 眼, 耳, 
精神および全ての感覚機能は 10 年ごとに順番に低下する,と言うものもある( $A S$ 2.8.20-23)」と老化の過程を述べているのは興味深い。

\section{寿命の测定：}

医師が患者を治療するときにまず始めに患者の寿命を知ることが重要であっ たことは，SS 1.35.3の「患者を治療するときには，医師はまず始めに，その寿 命を調べるべきである。もし寿命があるときには，それから病気（治癒しうる病 気か否か), 季節 (アグニ, 体力は季節に依存), アグ二(消化力), 年齢, 体力, 純質 (思考器官の活動), 習慣 (食事, 運動など), 体質 (ヴァータ体質, ピッ夕体質, カパ体

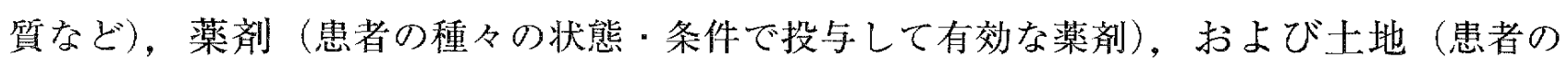
住所が乾燥地か湿地かなど）を調べるべきである」という記述から䝷うことができ る。医学文献ではない『ミリンダ王の問い』2.91にも，「寿命のつきた者には護 呪(パリッ夕）のほかあらゆる薬草や医薬も役立たない」と述心゙られており，寿 命に残りがある者にのみ護呪や医薬を使用したことが示唆される。

インド医学古典 SSには,「この寿命の長さを知るために身体の部分（身幹, 上肢, 下肢および頭）と副部分（各部分のより小さい部分）の量（長さ）を指の幅（横指）に より测定すると同時に sāra（体質あるいは精神の構成主成分, 医学的用語であるダーツ と同じ意味) を調べるべきである，身体の寸法については，この正規の理想的な 寸法を持つ八は長寿と多くの財を，中等度の寸法なら中等度の寿命と財を，少な い寸法なら同様に少ない寿命と財を得ることになる（SS 1.35.12-15）。 sāraについ ては，精神機能，身体器官，身体機能の特徵により純質，精液，骨䯣，骨，脂肪， 笳肉，血液，皮膚のいかなる身体構成要素が優位かを調べこれらの主成分のう ち前記のものほど寿命と幸福に打いて優れている（SS 1.35.16）」と述べられてい 马.

\section{寿命の長短の特徴 :}

CS 4.8.51 に小児における長寿の身体的特徵を, 髪, 皮虐, 頭, 額, 耳, 買, 眼, 鼻，口，舌，口蓋，声，口唇，顎，首，胸，頸の基部の骨（鎖骨）と背骨，乳房， 肋骨領域, 腕 -下腿 - 指, 手足, 手の爪, 臍, 腰部, 慰部, 大腿部, 下腿, 踝, 足について述べ, ガス・尿・便・外陰部, 睡眠・覚醒・運動・笑うこと・泣くこ と・乳を吸うこと，ほかの何であれ述へられていないものについては生来の性質 をそなえているもの，と詳細に述べているＳSSにも寿命の長さと身体の特徴に つき長寿の特徴 (SS 1.35.4-6), 中等度の寿命の特徴（SS 1.35.7-9ab），短い寿命 の特徴 (SS 1.35.9cd-11) が述べられているが, CSの内容と類似している. 
以上のごとく，古代インドにおいては，医師は，治療する前に先ず患者の寿命 を調べなければならなかったが, 寿命を知る方法はインド医学古典と同時代に成 立した『ブリハット・サンヒター』67.1-116（『占術大集成』2.21-37）に述べられ ている人相学や手相学的なものが多いと思われる.一方, 16 世紀に成立したと される『バーヴァプラカーシャ』1.6（1）54-58においては，比較的科学的な寿 命の評価が行われていたことが窺える。

寿命の決定：

古代インド医学においては, 全ての生類の寿命は, 天命（前世の行為）と人為（現 世の行為）の強さが軽度, 中等度, 高度であるかと, その両行為の組み合わせ, すなわち天命と人為の相対的な強さにより決まると考えていた（CS 3.3.29-35). $A S$ 1.9.83-88にもほぼ同様に述べられているが,『ヤージュニャヴァルキヤ法典』 1. 344-346や『マ又法典』7.205などの法典のほか『マハーバーラ夕』ボンベイ版, アーディ・パルヴァン 123. 21 ; シャーンティ・パルヴァン 153.50 などの医学書 でない文献にも，寿命についてではないが，人間の行為の成就は天命と人為に依 存していることが述べられており，古代インドにおける前世・現世・来世の信仰 を示すものと思われる。

寿命の決定は生前か否か？：

1 ）寿命が生前に決定しているとすれば,

何人にも不慮の死は起こらないことになるが,インド医学古典 CS 3.3.36には， 「寿命が前もって決められていれば, 長寿の人々にマントラ, 薬草, 護符などを 考慮することはないし, 興奮した, 恐ろしい猛獣・暴風, 瀑布・山など, 精神病 者, 敵, 激しい火, 有毒な蛇など, 場所や時間に不適切な行為や王の怒りを避け る必要がない。また，聖者の導入・逸話・応用・知識のほかインドラやアシュヴィ ン双神による治療も無用であろう。一方，同し戦争に立ち上がった人と立ち上が らなかった人，病気に罹患したとき対処した人と対処しない人，毒でないものを 摂取した人と毒であるものを摄取した人に寿命に違いがあることはないはずであ る」と述べられている．寿命が生前に決まっていなければ，現世の行為により決 まるから，適切に指導し，適切に観察するのである.

以上のことは，寿命は生前に決められていないとの考えを持つものが多数いた ことを示すものであろう.『マハーバーラタ』ボンベイ版, シャーンティパルヴァ ン 58.13-16に述べられている「成就には天命より人為が優位である」との記述 と一致する。 


\section{2 ）寿命が生前に決定していないとすれば,}

寿命が前もって決められていないとすれば，「時宜を得た死」と「不慮の死」 が考えられる.CS 3.3.38 は両者の差異を乗り物と車軸との関係を譬えにして以 下のごとく述べている，『「時宜を得た死」は，身体に備わった寿命は本来的に力 があるが，適切に治療されていても，自分自身の寿命が尽きることにより終わる 死，古なわち寿命を全うする人の死である。「不慮の死」は, 過度の努力, 消化 力に不適切な食事, 不規則な食事, 困難な姿勢, 性交に耽溺すること, 悪い人と の交際，駆り立てられた衝動の抑制，動物・毒・火や風による障害，（適切な）食 物や治療楽を避けること，誤った治療などによる死であり，自分自身の寿命を全 うしない死である』と述べている.

AS 1.9.89-108にも「時宜を得た死」と「不慮の死」とにつき同様なことが述 ベられているが, 紀元前 1 世紀から紀元後数世紀内に成立した『ミリンダ王の問 い』3.72-84にも，死には「死すべき時がきての死」と「死妨べきでない時 の死」とがあり, 各々の原因を列挙し, 医学古典の内容と極めて類似している. 医学の専門書でないにもかかわらず，死の原因として業の報いのほかアーユル ヴェーダの病因論であるトリドーシャ説なども述べられていることから，初期の 仏教僧伽での医療とアーユルヴェーダとの密接な交流があったことが示唆され る. $A S$ 1.9.93 に仏教徒の寿命に関する主張が述べられていること, Zyskがパー リ・ヴィナヤの検討により初期仏教徒の伝統とインド医学古典との類似点のみな らず差異を述べていることも（K.G. Zysk, 1993.96-103)，この見解を支持するもの である。

\section{3. 考察}

現代医学的には, 寿命を決めているのは遺伝的体質と環境要因である. 古代イ ンド医学書に扔いても，長寿の相が詳細に述べられていること，患者を診察する 際まずその患者の寿命を調べるべきであると述べられていることから，長生きの 家系という遺伝的素因を重視していたものと思われる。しかし，寿命は天命と人 為の相対的な強さにより決められると考えていたため, 人為の作用を強め, 不慮

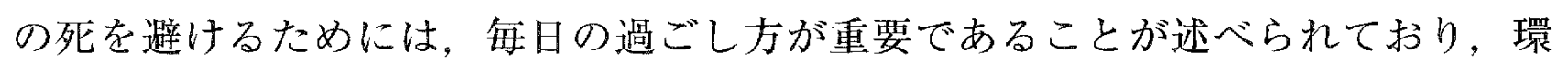
境要因をも重視したものと思われる.

寿命は前もって決まっているのでなく, 遺伝的な要因と環境要因により決定さ れるとの古代インドの見解は，現代医学と同様であり，長寿を得るための健康に 
よい生活を心がけ，不慮の死を回避することが重要である。かと言って，寿命が 長いだけでは必ずしも幸せと言えないことは，有名なグリム童話集のDie Lebenszeit (Kinder-und Hausmärchen 176) が示唆するように，寿命につきわれわれが 考えなければならない問題である。

\section{〈参考文献〉}

Atharvavedasamhita $\bar{a}$, translated into English by W. D. Whitney, NAG Publishers Delhi, 1987.

Aștāingasamgraha, text, English translation, Notes and Index by K. R. S. Murthy, 2001, Chaukhambha Orientalia, Varanasi, 2001.

Rgvedasamhita , edited \& revised with an exhaustive Introduction and notes by Ravi Prakash Arya \& K. L. Joshi., Parimal publications. Delhi, 2001.

Bhāvaprakāśa of Bhāvamiśra, text, English Translation, Notes, Appendeces and Index by K. R. S. Murthy, Krishnadas Academy, Varanasi, 2001.

Brüder Grimm, Kinder- und Hausmärchen, Philipp Reclam jun. Stuttgart, 1857.

Carakasamhitā, text with English translation by P. V. Sharma, Chaukhambha orientalia, Varanasi, 1996.

Mahābhārata, Sanskrit Text and English Translation, by M. N. Dutt, Parimal Publications, Delhi, 2004.

Zysk, K. G., Asceticism and Healing in Ancient India. Motilal Banarsidass Publishers, Delhi, 1998. ヴァラーハミヒラ, 『占術大集成」, 矢野道雄, 杉田瑞枝訳, 東洋文庫 590 , 平凡社, 1995.

『マヌ法典』, 渡瀨信之訳, 中公文庫, 中央公論社, 1991 .

『ミリンダ王の問い』2，3，中村元・早島鏡正訳，東洋文庫 15，平凡社， 1992 .

『ヤージュニヤヴァルキヤ法典』, 井狩弥介, 渡瀬信之訳, 東洋文庫 698, 平凡社, 2002.

〈キーワード〉 古代インド医学, アーユルヴェーダ, 寿命, 天命, 人為

(東京大学大学院) 